\title{
Sustainable Supply Chain Management: Insights from Australia's Firms
}

\author{
Mehadi Mamun ${ }^{1}$ \\ ${ }^{1}$ Faculty of Business Administration, Victorian Institute of Technology, Australia \\ Correspondence: Mehadi Mamun, Faculty of Business Administration, Victorian Institute of Technology, \\ Australia. E-mail: mehadibd@gmail.com
}

Received: May 24, 2021

Accepted: September 30, 2021

Online Published: October 20, 2021

doi:10.5539/ijbm.v16n11p99

URL: https://doi.org/10.5539/ijbm.v16n11p99

\begin{abstract}
While the sustainable supply chain is an emergent area of interest, the literature provides little guidance on how best to carry out sustainable supply chain management. The purpose of this paper is to provide hints to businesses on how best to approach the challenge of developing a sustainable supply chain. Hence, the case studies method is undertaken to explore how Australia's companies that are prominent worldwide for their sustainability performance have approached the challenge of managing sustainability in their supply chain. This study finds that sustainability action plans and governance tools that rightly reflect requisites for suppliers, diverse evaluation means to measure the suppliers' performance, and regular reviews of sustainable supply chain management practices and policies enable businesses to manage sustainability in their supply chain. The study contributes to the literature by providing a best practice model from the findings to provide practical guidance to businesses.
\end{abstract}

Keywords: sustainability, supply chain management, Australia

\section{Introduction}

The transformation of conventional supply chain management (SCM) into sustainable supply chain management (SSCM) creates enormous pressure on companies to make adjustments to their existing supply chain to meet the sustainability requisites (Busse et al., 2017). Sustainable supply chain management is a management process that incorporates the two fields of SCM and sustainability (Beske \& Seuring, 2014). SCM is the assimilation of major business processes, which delivers products, services, resources, and information from suppliers to consumers that add value for consumers and other stakeholders (Lambert \& Cooper, 2000), and sustainability is conceptualised by its principles and dimensions (economic, environmental, and social) for the welfare of businesses, environment and social systems for a sustainable future (Mc Loughlin, 2018). Hence, Ahi and Searcy (2013, p. 339) define sustainable supply chain management as "the creation of coordinated supply chains through the voluntary integration of economic, environmental, and social considerations with key inter-organisational business systems designed to efficiently and effectively manage the material, information, and capital flow associated with the procurement, production, and distribution of products or services in order to meet stakeholder requirements and improve the profitability, competitiveness, and resilience of the organisation over the short- and long-term."

Firms that desire to enhance the sustainability in their supply chains need to be more proactive in monitoring their suppliers across a range of business activities and entail a greater strategic promotion of performance on sustainability to enable coordination across manufacturing, distribution, and marketing activities (Beske et al., 2014; Hassini et al., 2012). Busse et al. (2017), Fahimnia et al. (2017), and Govindan et al., (2015) argue that businesses with a formal line to monitor sustainability practices in their supply chain experience performance advantages, greater engagement with all stakeholders, and improved corporate reputation. While several researchers have highlighted the significance of integrating sustainability into the businesses' purchasing decisions (Fahimnia et al., 2017; Govindan et al., 2015; Ahi \& Searcy, 2013), the research offers not much guidance on how best to achieve this goal. Therefore, the objective of this paper is to find out in what ways Australia's firms that are well-known worldwide for their sustainability performance respond to the opportunities and challenges related to pursuing sustainability in the supply chain. The present study, hence, seeks to explore the following research question: How do Australia's companies that are renowned for sustainability 
performance take up sustainability in their supply chain? This study contributes to the literature by providing a common practice model for SSCM, which can also be followed by the other companies as exemplary.

The remainder of the paper is structured as follows. The next section outlines an overview of relevant literature on sustainable supply chain management, the third section draws the research method, while the fourth section provides the research findings. Concluding remarks, limitations, and scopes for further research are made in the fifth section.

\section{Literature Review}

Due to the increasing globalisation of the world economy, constructing, managing and interacting within the supply chain has turned out to be a challenging task (Genovese et al., 2017). While traditional supply chain management mostly focuses on the economic outlooks, sustainable supply chain management is linked with the assimilation of the environmental and social objectives along with the economic objective (Tseng et al., 2015; Wittstruck \& Teuteberg, 2012). Fahimnia et al. (2017), Govindan et al., (2015), and Glover et al., (2014) find that the businesses that embrace sustainable activities have competitive advantages and long-term economic benefits. The economic perspective of SSCM focuses on the incorporation of sustainability criteria in such a way that profitability is achieved with efficient management of the environment and social resources (Carter \& Easton, 2011). Hence, Ortas et al. (2014) and Carter and Rogers (2008) focus on the embracing of environmental and social measures along the lines of the firm's economic objectives.

The environmental perspective in sustainable supply chain management is largely about the protection of the environment that the supply chain is working in. The environmental aspect of sustainable supply chain management involves the goals, action plans, and practices that promote grander environmental responsibility and support eco-friendly knowhows (Min \& Kim, 2012). Mota et al. (2015) and Wiese et al. (2012) suggest a few sustainable supply chain management activities that can be incorporated into the business strategies, such as effective product design that utilise reusable and recycled materials, eco-friendly packaging and warehousing, and suitable working conditions. Van Hoof and Thiell (2014) and Darnall et al. (2008), therefore, suggest the firms to act closely with their suppliers to enhance the environmental performance of their production processes and products, and advise their suppliers to take on sustainable measures such as ethical labour practices and sensible utilisation of natural resources. Customers also favour green packaged products and firms' green procurement strategies in recent times due to the growing environmental worries (Tonelli et al., 2013). Kuik et al. (2011), hence, suggest the firms to adopt sustainability in the supply chain, and classify sustainable supply chain management into 3R's such as recycle, reuse, and remanufacture for process development, and reduce, recover, and redesign for product design.

The social aspect of sustainable supply chain management is inclusive of society, organisations, and individuals. The social facet of sustainability is one of the most essential facets in sustainable supply chain management as organisations include various stakeholders with different perspectives and goals, and managing this variant sets a challenge to managers (Hall \& Matos, 2010). Social sustainability is about the management of social values and justice, human rights, and the welfare of workers, people, and the whole society (Simoes et al. 2014; Sarkis et al., 2010). Social sustainability is directly linked to corporate social responsibility, which brings the idea that a firm should meet the economic, ethical, legal, and other expectations of stakeholders keeping in mind the environmental and societal needs (Sarkis et al., 2010; Defee et al., 2009). Hence, Simoes et al. (2014) and Harms et al. (2013) suggest that the supplier management strategies should involve guiding the suppliers to carry out sustainable supply chain practices and take into account stakeholders' concerns in the decision-making process.

Gimenez and Tachizawa (2012) also concentrate on a firm's governance mechanisms that help to implement its sustainable strategies and improve sustainability performance. Formentini and Taticchi (2016) define sustainable supply chain governance as a set of numerous actions to consolidate relationships with the inter-organisational sectors, supply chain actors, activities, and stakeholders to achieve the sustainability goals. Gimenez and Sierra (2013) and Vurro et al. (2009) argue that a collaborative relationship with the suppliers generates the maximum impact in the supplier's actions for sustainability, and collaborative governance act as a robust means for the promotion of sustainable supply chain management. In a non-collaborative situation, Formentini and Taticchi (2016) suggest imposing a firm's decisions and set the governance to the supply chain counterparts through the contractual power. The present study, therefore, investigates how Australia's companies that are prominent worldwide for their sustainability performance have dealt with the economic, environmental, social, and governance issues in their supply chain. 


\section{Research Method}

Since the field of SSCM is relatively new (Touboulic \& Walker, 2015), the purpose of this study is to look at how Australia's companies that are renowned worldwide for their sustainability performance have practiced to take up the sustainability in their supply chain. This study, therefore, employs the case study research method as this research technique focuses on a contemporary phenomenon in a factual context (Yin, 2014).

The Dow Jones Sustainability Australia Index, which is the most cherished independent sustainability ranking system that benchmarks publicly listed firms' performance across the industry and evaluates what progress they are making in terms of achieving their strategic sustainability goals (Searcy \& Elkhawas, 2012), has published the top 10 publicly listed Australia's companies by sustainability index weight in 2020. Of the 10 companies, the top six companies have been considered for this study as the development of similar findings over multiple cases help to generalise findings. The names of those top six companies, which span different industries are presented in Table AI (see Appendix). Content analysis of secondary information is the key instrument used in this study as this research means has been widely used in examining companies' practices on sustainability disclosure (Talbot \& Boiral, 2015; Bowen, 2009). Hence, the sample of six companies' annual reports, websites, CSR reports or sustainability reports, and supply chain guides have been used to find out their approaches to sustainable supply chain management.

\section{Cross-Case Findings}

The study finds that all of the sample case study organisations recognise the value of corporate social responsibility to their supply chain and highlight the need to monitor their suppliers' sustainability performance. As part of the SSCM strategy, companies' initiatives include (i) SSCM policy development, (ii) current suppliers' performance data collection and potential new suppliers' screening, and (iii) supplier management and development of a code of conduct for them. In the policy documents, companies convey a clear statement of the principles and goals pertaining to SSCM. It includes a guideline for the existing suppliers and methods for weighing new suppliers, which comprise details on requirements for suppliers in the areas of economic, environmental, social, and governance issues.

To assess current suppliers' performance and screen new suppliers, a questionnaire is used to collect data on their performance. The questionnaire of about 100 questions, which is informed by the Daw Jones Sustainability Index and discussion with sustainability experts, captures information on how suppliers minimise their environmental impacts, and their policies in the other areas of sustainability, such as labour practices, human rights, and community involvement of social aspect of sustainability. Table 1 presents an outline of the different aspects of sustainability contained in the questionnaire where each topic of the questionnaire examines the extent of strategic position, commitment, and resource investment made by the suppliers.

Table 1. The SSCM questionnaire's elements

\begin{tabular}{llll}
\hline Economic & Environmental & Social & Governance \\
\hline Economic performance & Policies & Diversity & Policies \\
Market presence & Targets & Anti-discrimination & Management systems \\
Industry-specific criteria & Eco-performance & Child and forced labour & Crisis management \\
& Product stewardship & Human-capital development & Codes of conduct, anti-corruption, \\
& Environmental reporting & Quality of working life & Public reporting \\
& & Workplace health and safety & Collaboration with procurer \\
& & Community involvement's policy, & activities and impacts
\end{tabular}

The study also finds that all the studied organisations have formed a code of practice that indicates the minimum corporate social responsibility requirements for all of their suppliers and offers a self-compliance template for them. In the four cases, small suppliers are not needed to fulfil the SSCM questionnaire, instead, they are expected to dedicate themselves to the standards required by the code and fill up the self-compliance template. Each year, a sample of suppliers is also audited against the responses to the SSCM questionnaire and the code to assess their actual performance against their policies and management systems, and know how to better use 
resources to support the suppliers to improve their performance on sustainability.

\section{Conclusion, Limitations, and Future Research}

While the previous studies offer little guidance on how best to pursue the goal of integrating sustainability into the businesses' purchasing decisions, the present paper's objective is to provide a guide on how to respond to the opportunities and challenges related to pursue sustainability in the supply chain through adopting strategies of Australia's firms that are well-known worldwide for their sustainability performance. Following a review of the literature, hence, case studies approach is employed to explore how Australia's six best companies that are prominent worldwide have incorporated the challenge of adopting sustainability-oriented purchasing strategies. Deriving from the findings, therefore, this paper offers a guide for companies wishing to adopt similar strategies, such as (i) develop sustainability action plans and governance tools that aptly reflect requisites for suppliers, (ii) develop diverse evaluation means to measure the suppliers' performance and compliance, and (iii) carry out regular reviews of SSCM practices and policies to make improvements where necessary.

It is worth mentioning here that the present study should be read with caution, as it is solely based on disclosures made by companies in the public domain. Further research is, thus, warranted to employ other research methods, and recognise the experiences and thoughts of managers and other stakeholder groups. Future research can also be built on this study by exploring whether these strategies can be generalised across geographic boundaries and businesses.

\section{References}

Ahi, P., \& Searcy, C. (2013). A comparative literature analysis of definitions for green and sustainable supply chain management. Journal of Cleaner Production, 52, 329-341. https://doi.org/10.1016/j.jclepro.2013.02.018

Beske, P., \& Seuring, S. (2014). Putting sustainability into supply chain management. Supply Chain Management-an International Journal, 19(3), 322-331. https://doi.org/10.1108/SCM-12-2013-0432

Beske, P., Land, A., \& Seuring, S. (2014). Sustainable supply chain management practices and dynamic capabilities in the food industry: A critical analysis of the literature. International Journal of Production Economics, 152, 131-143. https://doi.org/10.1016/j.jpe.2013.12.026

Bowen, G. (2009). Document analysis as a qualitative research method. Qualitative Research Journal, 9(2), 27 40. https://doi.org/10.3316/QRJ0902027

Busse, C., Meinlschmidt, J., \& Foerstl, K. (2017). Managing information processing needs in global supply chains: A prerequisite to sustainable supply chain management. Journal of Supply Chain Management, 53(1), 87-113. https://doi.org/10.1111/jscm.12129

Carter, C. R., \& Rogers, D. S. (2008). A framework of sustainable supply chain management: moving toward new theory. International Journal of Physical Distribution \& Logistics Management, 38(5-6), 360-387. https://doi.org/10.1108/09600030810882816

Carter, C.R., \& Easton, P.L. (2011). Sustainable supply chain management: evolution and future directions. International Journal of Physical Distribution \& Logistics Management, 41(1), 46-62. https://doi.org/10.1108/09600031111101420

Darnall, N., Jolley, G.J., \& Handfield, R. (2008). Environmental management systems and green supply chain management: complements for sustainability? Business Strategy and the Environment, 17(1), 30-45. https://doi.org/10.1002/bse.557

Defee, C.C., Stank, T.P., Esper, T.L., \& Mentzer, J.T. (2009). The role of followers in supply chains. Journal of Business Logistics, 30(2), 65-84. https://doi.org/10.1002/j.2158-1592.2009.tb00112.x

Fahimnia, B., Sarkis, J., Gunasekaran, A., \& Farahani, R. (2017). Decision models for sustainable supply chain design and management. Annals of Operations Research, 250(2), 277-278. https://doi.org/10.1007/s10479-017-2428-0

Formentini, M., \& Taticchi, P. (2016). Corporate sustainability approaches and governance mechanisms in sustainable supply chain management. Journal of Cleaner Production, 112, 1920-1933. https://doi.org/10.1016/j.jclepro.2014.12.072

Genovese, A., Acquaye, A.A., Figueroa, A., \& Koh, S.L. (2017). Sustainable supply chain management and the transition towards a circular economy: evidence and some applications. Omega, 66 (Special Issue), 344-357. https://doi.org/10.1016/j.omega.2015.05.015 
Gimenez, C., \& Sierra, V. (2013). Sustainable supply chains: governance mechanisms to greening suppliers. Journal of Business Ethics, 116(1), 189-203. https://doi.org/10.1007/s10551-012-1458-4

Gimenez, C., \& Tachizawa, E.M. (2012). Extending sustainability to suppliers: a systematic literature review. Supply Chain Management: An International Journal, 17(5), 531-543. https://doi.org/10.1108/13598541211258591

Glover, J. L., Champion, D., Daniels, K. J., \& Dainty, A. J. D. (2014). An institutional theory perspective on sustainable practices across the dairy supply chain. International Journal of Production Economics, 152(Special Issue), 102-111. https://doi.org/10.1016/j.jpe.2013.12.027

Govindan, K., Jafarian, A., \& Nourbakhsh, V. (2015). Bi-objective integrating sustainable order allocation and sustainable supply chain network strategic design with stochastic demand using a novel robust hybrid multi-objective metaheuristic. Computational Operations Research, 62(October), 112-130. https://doi.org/10.1016/j.cor.2014.12.014

Hall, J., \& Matos, S. (2010). Incorporating impoverished communities in sustainable supply chains. International Journal of Physical Distribution and Logistics Management, 40(1-2), 124-147. https://doi.org/10.1108/09600031011020368

Harms, D., Hansen, E.G., \& Schaltegger, S. (2013). Strategies in sustainable supply chain management: an empirical investigation of large German companies. Corporate Social Responsibility and Environmental Management, 20(4), 205-218. https://doi.org/10.1002/csr.1293

Hassini, E., Surti, C., \& Searcy, C. (2012). A literature review and a case study of sustainable supply chains with a focus on metrics. International Journal of Production Economics, 140(1), 69-82. https://doi.org/10.1016/j.ijpe.2012.01.042

Kuik, S.S., Verl Nagalingam, S., \& Amer, Y. (2011). Sustainable supply chain for collaborative manufacturing. Journal of Manufacturing Technology Management, 22(8), 984-1001. https://doi.org/10.1108/17410381111177449

Lambert, D. M., \& Cooper, M. C. (2000). Issues in supply chain management. Industrial Marketing Management, 29(1), 65-83. https://doi.org/10.1016/S0019-8501(99)00113-3

Mc Loughlin, K. (2018). Sustainable supply chain management: a case study of a sustainable chocolate supply chain network. Doctoral thesis (PhD), Manchester Metropolitan University.

Min, H., \& Kim, I. (2012). Green supply chain research: past, present, and future. Logistics Research, 4(1-2), 39-47. https://doi.org/10.1007/s12159-012-0071-3

Mota, B., Gomes, M.I., Carvalho, A., \& Barbosa-Povoa, A.P. (2015). Towards supply chain sustainability: environmental and social design and planning. Journal Cleaner Production, 105(Special Issue), 14-27. https://doi.org/10.1016/j.jclepro.2014.07.052

Ortas, E., Moneva, J. M., \& Alvarez, I. (2014). Sustainable supply chain and company performance A global examination. Supply Chain Management-an International Journal, 19(3), 332-350. https://doi.org/10.1108/SCM-12-2013-0444

S\&P Dow Jones Indices (2020). Dow Jones Sustainability Australia Index. Available at https://www.spglobal.com/spdji/en/indices/esg/dow-jones-sustainability-australia-index

Sarkis, J., Gonzalez-Torre, P., \& Adenso-Diaz, B. (2010). Stakeholder pressure and the adoption of environmental practices: The mediating effect of training. Journal of Operations Management, 28(2), 163-176. https://doi.org/10.1016/j.jom.2009.10.001

Searcy, C., \& Elkhawas, D. (2012). Corporate sustainability ratings: An investigation into how corporations use the Dow Jones Sustainability Index. Journal of Cleaner Production, 35, 79-92. https://doi.org/10.1016/j.jclepro.2012.05.022

Simoes, M., Carvalho, A., de Freitas, C.L., \& Barbosa-Povoa, A. (2014). How to assess social aspects in supply chains? Computer Aided Chemical Engineering, 34, 801-806. https://doi.org/10.1016/B978-0-444-63433-7.50118-8

Talbot, D., \& Boiral, O. (2015). Strategies for climate change and impression management: A case study among Canada's large industrial emitters. Journal of Business Ethics, 132(2), 329-346. https://doi.org/10.1007/s10551-014-2322-5 
Tonelli, F., Evans, S., \& Taticchi, P. (2013). Industrial sustainability: challenges, perspectives, actions. International Journal of Business Innovation and Research, 7(2), 143-163. https://doi.org/10.1504/IJBIR.2013.052576

Touboulic, A., \& Walker, H. (2015). Theories in sustainable supply chain management: a structured literature review. International Journal of Physical Distribution and Logistics Management, 45(1-2), 16-42. https://doi.org/10.1108/IJPDLM-05-2013-0106

Tseng, M., Lim, M., \& Wong, W.P. (2015). Sustainable supply chain management: a closed-loop network hierarchical approach. Industrial Management and Data Systems, 115(3), 436-461. https://doi.org/10.1108/IMDS-10-2014-0319

Van Hoof, B., \& Thiell, M. (2014). Collaboration capacity for sustainable supply chain management: small and medium-sized enterprises in Mexico. Journal of Cleaner Production, 67, 239-248. https://doi.org/10.1016/j.jclepro.2013.12.030

Vurro, C., Russo, A., \& Perrini, F. (2009). Shaping Sustainable Value Chains: Network Determinants of Supply Chain Governance Models. Journal of Business Ethics, 90, 607-621. https://doi.org/10.1007/s10551-010-0595-x

Wiese, A., Kellner, J., Lietke, B., Toporowski, W., \& Zielke, S. (2012). Sustainability in retailing-a summative content analysis. International Journal of Retail and Distribution Management, 40(4), 318-335. https://doi.org/10.1108/09590551211211792

Wittstruck, D., \& Teuteberg, F. (2012). Understanding the success factors of sustainable supply chain management: empirical evidence from the electrics and electronics industry. Corporate Social Responsibility and Environmental Management, 19(3), 141-158. https://doi.org/10.1002/csr.261

Yin, R. K. (2014). Case Study Research: Design \& Methods (5th ed.). California: Sage.

\section{Appendix 1}

Table AI. The names of the sample Australian companies and their sectors

\begin{tabular}{ll}
\hline Australian companies & Sector \\
\hline BHP Group Ltd & Materials \\
National Australia Bank Ltd & Financials \\
Westpac Banking Corp & Financials \\
ANZ Banking Group & Financials \\
Wesfarmers Ltd & Consumer Discretionary \\
Transurban Group NPV & Industrials \\
\hline
\end{tabular}

Source: S\&P Dow Jones Indices (2020)

\section{Copyrights}

Copyright for this article is retained by the author(s), with first publication rights granted to the journal.

This is an open-access article distributed under the terms and conditions of the Creative Commons Attribution license (http://creativecommons.org/licenses/by/4.0/). 